\title{
In het spoor van Radbruch. De Nederlandse rechtsfilosofie en de erfenis van de oorlog (1946-1949)
}

\author{
Wouter Veraart
}

'Niet als het rechtsleven rustig voortvloeit, is er tijd en aandacht voor rechtsfilosofie; maar als het opgeschrikt en geschokt wordt, prest dat jurist en niet-jurist tot filosoferen over staat en gerechtigheid. Dat gezichtspunt brengt perspectief in ons herdenken. Trekken wij dit perspectief door en letten wij op wat, na de oorlog en bezetting, nu ook bevrijding en "wederopbouw" tot dusver hebben gebracht, dan lijkt wellicht nog verdere bloei voor de rechtsfilosofie en voor onze Vereniging weggelegd.' 1

\section{Inleiding}

Hoe was het met de Nederlandse rechtsfilosofie gesteld in de eerste jaren na de bevrijding? De Duitse bezetting liet ook de Vereniging voor Wijsbegeerte des Rechts (VWR) niet onberoerd. ${ }^{2}$ In de eerste vijftien jaar na de bevrijding lag binnen de VWR het rechtsfilosofische accent op de verhouding tussen recht en gerechtigheid in het licht van het recente verleden. ${ }^{3}$ Dat thema werd binnen de nog sterk verzuilde VWR op verschillende wijzen aangesneden. Hoewel de voordrachten die in dit tijdvak binnen de VWR worden gehouden een hoge graad van abstractie kenden, moet hun praktische relevantie niet worden onderschat. ${ }^{4}$ De respons op het bezettersonrecht stond immers ook in de rechtspraktijk centraal. Het herstel van het rechtsverkeer ging niet slechts over de gedeeltelijke ongedaanmaking van allerlei gedwongen transacties die in de bezettingsjaren hadden plaatsgevonden, maar ook over het herstel van vertrouwen in de rechtsorde zelf. ${ }^{5}$

1 Maarten P. Vrij, 'Herdenkingsrede', uitgesproken tijdens de vergadering van 17 december 1949, Handelingen van de Vereniging voor Wijsbegeerte des Rechts XXXIV 2 (1949): 5-6.

2 Zie ook de bijdrage van Corjo Jansen, Het 100-jarige bestaan van de Vereeniging voor Wijsbegeerte des Rechts, elders in dit nummer.

3 Zie de appendix bij dit artikel. In veertien van de zeventien gehouden inleidingen tot en met 1959 speelt de relatie tussen recht en moraal, gerechtigheid of ethiek een voorname rol. Tot en met 1955 gaat het zelfs om alle inleidingen.

4 Met deze bijdrage beoog ik ook het beeld bij te stellen dat Corjo Jansen van deze periode in zijn artikel schetst. Zie Jansen, Het 100-jarige bestaan, elders in dit nummer: 'De wens van de oprichters om de rechtspraktijk bij de activiteiten van de VWR te betrekken, leek zo goed als prijsgegeven. De rechtsfilosofie voer een eigen koers ten opzichte van de ontwikkelingen in het positieve recht. De onderwerpen voor de preadviezen werden daarmee steeds meer (rechts)filosofisch en meer beschouwelijk van aard.'

5 Wouter Veraart, Ontrechting en rechtsherstel in Nederland en Frankrijk in de jaren van bezetting en wederopbouw (Deventer: Kluwer, 2005). 
Bij de meest actieve leden van de VWR springt daarbij in het oog dat de rechtsfilosofische voordrachten die zij binnen de Vereniging hielden, synchroon liepen met meer praktijkgerichte interventies in allerlei aan de nasleep van de oorlog gerelateerde debatten. De relatie tussen rechtsfilosofie en rechtspraktijk was daarmee hecht en persoonlijk - de rechtsfilosofie als discipline niet gescheiden van de verantwoordelijkheid die door deze juristen voor het daadwerkelijk herstel van de Nederlandse rechtsorde werd gevoeld.

In het navolgende wil ik het bovenstaande uitwerken door enkele interventies van drie van die actieve VWR-leden uit de eerste jaren van dit tijdvak (de periode 1946-1949) nader te belichten: Jhr. C.M.O. (Carel) van Nispen tot Sevenaer (1895-1995), I. (Izaak) Kisch (1905-1980) en G.E. (Gerard) Langemeijer (1903-1990). Voor deze drie leden geldt dat zij tussen 1946 en 1949 elk één en in het ruimere tijdvak 1946-1959 ten minste twee inleidende voordrachten hebben gehouden (zie appendix bij dit artikel) en ook overigens prominent aanwezig waren in de debatten die er naar aanleiding van de preadviezen binnen de VWR werden gevoerd. Gelet op het sterke accent op de relatie tussen recht en moraal in deze periode, is het niet verwonderlijk dat de rechtsfilosoof Gustav Radbruch vaak werd aangehaald in de onderlinge discussies en dat zijn op waarden georiënteerde benadering binnen de VWR veel bijval kreeg. Aan Radbruchs rechtsidee is daarom paragraaf 2 gewijd. In de paragrafen 3, 4 en 5 ga ik achtereenvolgens in op werk van Van Nispen tot Sevenaer, Kisch en Langemeijer met een focus op de periode 1946-1949, waarbij steeds de vraag centraal staat hoe hun denken zich verhoudt tot de rechtsfilosofie van Radbruch en de erfenis van de oorlog. Ik sluit af (in paragraaf 6) met een beknopte bespreking van de herdenkingsrede die door de toenmalige VWR-voorzitter, de Groningse strafrechtgeleerde M.P. (Maarten) Vrij (1895-1955), ${ }^{6}$ in december 1949 werd uitgesproken ter gelegenheid van het dertigjarig bestaan. Deze rede, waaruit ook het openingscitaat van dit artikel is genomen, markeert het eindpunt van vier jaar van bijzonder intensieve aandacht voor de rechtsfilosofische implicaties van de ervaring van juridisch onrecht.

\section{Radbruchs rechtsidee}

Toen Kisch in 1975 door Jan van Dunné werd geïnterviewd voor Acht Civilisten in Burger, kreeg hij de vraag waarom hij nooit een eigen rechtsleer had ontwikkeld. Daarop antwoordde Kisch: 'Ik geloof dat er aan een eigen rechtsleer niet veel te bouwen valt, omdat ik niet zie hoe je daarover aanmerkelijk beter of dieper zou kunnen schrijven dan Radbruch, die voor mij toch de grote man is. ${ }^{7}$ Bewondering voor Radbruch bestond er ook bij Langemeijer die bijvoorbeeld in zijn Inleiding tot

6 Zie Sjoerd Faber, 'M.P. Vrij (1895-1955)', in 16 juristen en hun filosofische inspiratie, red. Corjo Jansen, Jan Smits en Laurens Winkel (Nijmegen: Ars Aequi Libri, 2004), 99-106.

7 Jan van Dunné, Pieter Boeles en Arend Jan Heerma van Voss (red.), Acht civilisten in burger. (Zwolle: Tjeenk Willink, 1977), 117. Zie ook Laurens Winkel, 'I. Kisch (1905-1980)', in 16 juristen en hun filosofische inspiratie, red. Corjo Jansen, Jan Smits en Laurens Winkel (Nijmegen: Ars Aequi Libri, 2004), 177. 
de studie van de wijsbegeerte des rechts de nodige aandacht aan hem besteedt. ${ }^{8}$ Eind 1949 werd door VWR-voorzitter Vrij in zijn herdenkingsrede kort stilgestaan bij Radbruchs overlijden op 23 november van dat jaar: 'Zijn rechtsrelativisme moge ook de humanisten onder ons niet meer geheel bevredigen, zijn Grundzüge der Rechtsphilosophie heeft, in de eerste versie van 1914 en in de vernieuwde van later, geslachten van juristen voor de rechtswijsbegeerte gewonnen. De vrienden, die hij had en na den oorlog behouden kon, gedenken hem erkentelijk en genegen.' ${ }^{\text {' }}$

In Inleiding tot de studie des wijsbegeerte des rechts typeert Langemeijer Radbruchs rechtsidee als 'het centrale of in ieder geval belangrijkste deel van zijn leer'. Langemeijer vertaalt de drie waarden waaruit die rechtsidee is opgebouwd, Gerechtigkeit, Zweckmäßigkeit en Rechtssicherheit, als gerechtigheid, doelmatigheid ${ }^{10}$ en rechtszekerheid. ${ }^{11}$ Voor Langemeijer is het later vaak besproken verschil tussen de vooroorlogse en de naoorlogse Radbruch hooguit gradueel:

'De verwezenlijking van rechtszekerheid door het positieve recht geeft aan dit laatste een bijna volstrekte aanspraak op naleving, ook wanneer het ten opzichte van andere waarden ernstig tekortschiet. Toch kan dit tekortschieten tot een zodanig uiterste komen, dat de plicht tot gehoorzaamheid wegvalt. Men krijgt de indruk dat Radbruch deze mogelijkheid op den duur iets

8 Gerard Langemeijer, Inleiding tot de studie van de wijsbegeerte des rechts (Zwolle: Tjeenk Willink, 1970), 142-46, 223, 260, 263, 269.

9 Vrij, 'Herdenkingsrede', 7.

10 'Zweckmäßigkeit' wordt vaak vertaald als 'purposiveness', bijvoorbeeld door Stanley Paulson, 'On the Background and Significance of Gustav Radbruch's Post-War Papers', Oxford Journal of Legal Studies 26/1 (2006): 17-40; Heather Leawoods, 'Gustav Radbruch: An Extraordinary Legal Philosopher', Washington University Journal of Law \& Policy 2 (2000): 489-515; Thomas Mertens, 'Radbruch and Hart on the Grudge Informer: A Reconsideration', Ratio Juris 15/2 (2002): 186-205; Sanne Taekema, 'Value Pluralism and Legal Pluralism: Using Radbruch's Value-based Approach to Law to Understand Global Legal Pluralism', in Oxford Handbook of Global Legal Pluralism, red. Paul Schiff Berman (Oxford: Oxford University Press, in druk), of in het Nederlands als 'doelgerichtheid', bijvoorbeeld door Thomas Mertens, Mens \& mensenrechten. Basisboek rechtsfilosofie (Amsterdam: Boom, 2012), 82. Daartegenover wordt ook wel 'expediency' als vertaling gebezigd, zie bijv. Emil Lask, Gustav Radbruch en Jean Dabin, The Legal Philosophies of Lask, Radbruch, and Dabin (Cambridge Mass.: Harvard University Press, 2014). Cees Maris kiest net als Langemeijer voor doelmatigheid, zie Cees Maris, 'Algemene Inleiding', in Recht, Rechtvaardigheid en Doelmatigheid, red. Cees Maris, Anne Marie Bos, André Hoekema en Taco van Peijpe (Arnhem: Gouda Quint, 1990), 3-10. Voor een bredere omschrijving kiest Roger Cotterrell, 'The Role of the Jurist: Reflections around Radbruch', Ratio Juris 26/4 (2013): 516. Cotterrell vertaalt Zweckmäßigkeit heel ruim als '(suitability for) purpose [...], or expediency or utility'. Ook Robert Alexy volgt deze ruimere benadering in Robert Alexy, 'Gustav Radbruchs Rechtsbegriff', in 50 Jahre Rechtswissenschaftliche Fakultät der Christian-Albrechts-Universität zu Kiel, red. Andreas von Arnauld, Ino Augsberg en Rudolf Meyer-Pritzl (Tübingen: Mohr Siebeck 2018), 237-49. Bij Cotterrells en Alexy's benadering van het vertaalprobleem - doelmatigheid in de ruimste zin van dat begrip - sluit ik me in deze bijdrage aan.

11 Langemeijer, Inleiding tot de studie van de wijsbegeerte des rechts, 142. 
ruimer is gaan nemen, wat trouwens met de indrukken van het Hitler-regiem voor ogen begrijpelijk zou zijn.' ${ }^{12}$

Deze indruk van Langemeijer komt overeen met recente analyses van Radbruchs rechtsfilosofie waarin de continuïteit tussen zijn vooroorlogse en naoorlogse werk wordt benadrukt. ${ }^{13}$ In zijn Rechtsphilosophie presenteert Radbruch het recht als een normatieve onderneming die gericht is op de verwezenlijking van de drie genoemde kernwaarden, de drie 'bestanddelen' van de rechtsidee. ${ }^{14}$ Die zorgen echter ook voor onderlinge spanningen en tegenstrijdigheden (Antinomien) in de rechtsidee zelf. De drie kernwaarden verkeren onderling in een complexe driehoeksverhouding van aantrekken en afstoten: '[D]ie drei Bestandteile der Rechtsidee fordern einander - aber sie widersprechen zugleich einander. ${ }^{15}$ Ook de rangorde tussen de waarden staat niet vast, maar kan fluctueren. ${ }^{16}$

In verband met de drie bestanddelen van Radbruchs rechtsidee spreekt Roger Cotterrell in een artikel uit 2013 over 'a "triangle" of three central values - a triangle that can be stretched into different shapes depending on context; we might say that law as a structure of values has a variable geometry. ${ }^{17}$ In plaats van de relatie tussen de drie waarden als een 'triangle' of een Ideetriade ${ }^{18}$ (een geometrisch driehoek) te beschrijven, zou ik de circulariteit tussen deze drie waarden willen benadrukken, waarbij elk van de drie bestanddelen naar een ander tijdsframe verwijst. Bij rechtszekerheid gaat het erom stabiliteit in de rechtsverhoudingen te garanderen in het heden. Gerechtigheid belooft formele rechtsgelijkheid in de rechtsverhoudingen, implicerend dat grove inbreuken op die rechtsgelijkheid - veroorzaakt door feitelijk of juridisch onrecht uit het verleden - zullen worden gecorrigeerd. In die belofte van rechtsherstel - bij Radbruch voor privaaten strafrecht uitgewerkt als ausgleichende Gerechtigkeit ${ }^{19}$ - is dit bestanddeel van de rechtsidee dus primair gericht op het verleden. Doelmatigheid is een instrumentele waarde die centraal staat als het recht wordt ingezet ter verwezenlijking van maatschappelijke doeleinden. In dat kader is het recht primair gericht op de toekomst. Deze interpretatie van Radbruchs rechtsidee kan in het bestek van dit artikel niet verder worden uitgewerkt, maar kan wellicht wel illustreren waarom het zwaartepunt in de triade - afhankelijk van de specifieke context - van tijd tot

12 Langemeijer, Inleiding tot de studie van de wijsbegeerte des rechts, 142.

13 Paulson, 'On the Background'; Cotterrell, 'The Role of the Jurist'; Robert Alexy, 'A Defence of Radbruch's Formula', in Recrafting the Rule of Law: The Limits of Legal Order, red. David Dyzenhaus (Oxford: Hart, 1999), 32-33; Alexy, 'Radbruchs Rechtsbegriff'; Frank Haldemann, 'A Debate on Nazi Law', Ratio Juris 18/2 (2005): 162-78.

14 Gustav Radbruch, Rechtsphilosophie, herausgegeben von Erik Wolf und Hans-Peter Schneider (Stuttgart: K.F. Koehler Verlag, 1973), § 9, 164: 'Recht ist, was seinem Sinne nach die Rechtsidee zu dienen bestimmt ist.'

15 Radbruch, Rechtsphilosophie, §9, 166.

16 Radbruch, Rechtsphilosophie, §9, 165-166. Zie in dit verband ook Sanne Taekema, The Concept of Ideals in Legal Theory (Tilburg: Schoordijk Instituut, 2000), 71-74.

17 Cotterrell, 'The Role of the Jurist', 516.

18 Alexy, 'Radbruchs Rechtsbegriff', 244.

19 Radbruch, Rechtsphilosophie, § 4, 121-22. 
tijd kan verschuiven. Door die 'geometrische' flexibiliteit kan het utopisch potentieel van Radbruchs rechtsidee verbonden blijven met de bewerkelijke realiteit. Steeds blijft de mogelijkheid open dat aan alle, dus ook conflicterende, rechtsbelangen die aan heden, verleden én toekomst gerelateerd zijn, althans volgtijdelijk en in meer of mindere mate, 'recht' kan worden gedaan. Deze drieledige - in de praktijk uiterst complexe en nooit gelijktijdig of volledig te realiseren - aspiratie van de rechtsidee, waarbij beoogd wordt om aan elk van de drie bestanddelen op evenredige wijze recht te doen, verbindt Radbruch met het streven naar gerechtigheid in ruime zin. Daarbij verwijst hij naar het suum cuique van Ulpianus, ofwel de austeilende Gerechtigkeit, waarmee de rechtsorde in zijn geheel in een nauwe betrekking staat. ${ }^{20}$

Radbruchs drie bestanddelen of juridische kernwaarden worden veelal als min of meer aan elkaar gelijkwaardig aangemerkt. Radbruch zelf tekent daarbij aan dat de bestanddelen (formele) rechtvaardigheid en rechtszekerheid typisch juridische waarden zijn die zich aan het politieke strijdtoneel kunnen onttrekken, terwijl doelmatigheid daar steeds mee verbonden blijft. ${ }^{21}$ Doelmatigheid is voor haar uitwerking immers afhankelijk van de politieke keuze voor het inhoudelijk te verwezenlijken doeleinde. Zweckmäßigkeit kan bij Radbruch gericht zijn op de verwezenlijking van individuele, collectieve (bovenindividuele) of culturele (transpersonalistische) 'ethische goederen' die door Radbruch Individualwerte, Kollektivwerte en Werkwerte worden genoemd. ${ }^{22}$ Ook deze drie doeleinden kunnen met elkaar conflicteren. Robert Alexy spreekt in dit verband van de Zwecktriade. ${ }^{23}$ Omdat de vooroorlogse Radbruch zich neutraal opstelt ten opzichte van de keuze voor een van deze drie doeleinden - en om die reden met betrekking tot de vraag naar de gelding van recht genoegen neemt met zijn positiviteit, ten dienste van de rechtszekerheid $^{24}$ - is zijn vooroorlogse rechtsfilosofie vaak geduid als relativistisch en onder meer door H.L.A. Hart als rechtspositivistisch gekenschetst, al wordt die laatste karakterisering tegenwoordig bestreden en niet meer aannemelijk geacht. ${ }^{25}$

In zijn twee bekendste naoorlogse essays komt Radbruch op de drie kernwaarden terug. In 'Fünf Minuten Rechtsphilosophie' heeft Zweckmäßigkeit plaatsgemaakt voor Gemeinnutz. De verschrikkingen van het nationaalsocialistische rechtsregime hebben de inherente spanningen tussen de drie bestanddelen van de rechtsidee tot ondraaglijke hoogte opgevoerd. De positiviteit van recht kan in een dergelijke crisissituatie niet langer het enig mogelijke antwoord blijven geven op de vraag naar de gelding van onrechtvaardig of schadelijk recht. ${ }^{26}$

26 Voor een interessante beschouwing over het belang van het begrippenpaar normaal-uitzonderlijk in de rechtsfilosofie van Radbruch, zie Leawoods, 'Gustav Radbruch', 503-515. 
'Gewi $\beta$, menschliche Unvolkommenheit läßt im Gesetze nicht immer alle drei Werte des Rechts: Gemeinnutz, Rechtssicherheit und Gerechtigkeit, sich harmonisch vereinigen, und es bleibt dann nur übrig abzuwägen, ob dem slechten, dem schädlichen oder ungerechten Gesetze um der Rechtssicherheit willen dennoch Geltung zuzusprechen, oder um seiner Ungerechtigkeit oder Gemeinschädlichkeit willen die Geltung zu versagen sei. ${ }^{27}$

In het essay 'Gesetzliches Unrecht und übergesetzliches Recht' bespreekt Radbruch opnieuw de spanningen tussen de drie waarden. Niet langer is rechtszekerheid de enig beslissende waarde, net zo min als doelmatigheid: 'Keineswegs ist Recht alles das "was dem Volke nützt”, sondern dem Volke nützt letzten Endes nur, was Recht ist, was Rechtssicherheit schafft und Gerechtigkeit erstrebt.' Als recht de vorm krijgt van extreem onrecht, moet de gelding van het positief recht - ten dienste van de rechtszekerheid - voor de gerechtigheid wijken. Van extreem onrecht is sprake als de rechtsgelijkheid - bij Radbruch de kern van de gerechtigheid - op flagrante wijze wordt miskend (het 'extreem onrecht-criterium'):

'[...] eine Grenzziehung kann [...] mit aller Schärfe vorgenommen werden: wo Gerechtigkeit nicht einmal erstrebt wird, wo die Gleichheit, die den Kern der Gerechtigkeit ausmacht, bei der Setzung positiven Rechts bewußt verleugnet wurde, da ist das Gesetz nicht etwa nur "unrichtiges Recht", vielmehr entbehrt es überhaupt der Rechtsnatur.'28

\section{Het Nederlandse culminatiepunt: het Toetsingsarrest van 1942}

De crisis in Radbruchs rechtsidee culmineerde in de Nederlandse context in het debat over het controversiële toetsingsarrest van de Hoge Raad uit 1942. ${ }^{29}$ In dat arrest had de Hoge Raad kunnen beslissen dat de maatregelen van de Duitse bezetter aan het Haagse Landoorlogreglement (1907) konden worden getoetst. In dat geval had hij de rechtsgeldigheid van het Duitse bezettingsrecht kunnen beoordelen aan de hand van een internationaalrechtelijk juridisch kader waarin principes als proportionaliteit en rechtsgelijkheid leidend waren, die door de nazi's op tal van terreinen werden geschonden. Het hoogste rechtscollege zag daar echter van af, met een beroep op het argument dat de Duitse maatregelen op één lijn moesten worden gesteld met Nederlandse wetgeving waarvoor het grondwettelijk toetsingsverbod zou gelden. von Erik Wolf und Hans-Peter Schneider, Gustav Radbruch (Stuttgart: K.F. Koehler Verlag, 1973), 328.

28 Gustav Radbruch, 'Gesetzliches Unrecht und übergesetzliches Recht' [1946], in Rechtsphilosophie, herausgegeben von Erik Wolf und Hans-Peter Schneider, Gustav Radbruch (Stuttgart: K.F. Koehler Verlag, 1973), 345-46. Voor een recente Nederlandse vertaling van dit essay en deze passage zie Mertens, Mens en Mensenrechten, 76-87. HR 12 januari 1942, ECLI:NL:HR:1942:244 (Toetsingsarrest), NJ 1942, 271. 
De kans om de rechtsgeldigheid van het bezettingsrecht te toetsen aan hoger recht, gevat in internationaalrechtelijk gewaarborgde bepalingen en rechtsbeginselen, heeft de Hoge Raad daarmee laten passeren door zich onbevoegd te verklaren, met als gevolg dat hij, in de ogen van velen, indirect ook het grootste bezettersonrecht - in het bijzonder de anti-Joodse verordeningen waarvan een aantal toen reeds van kracht was - zou hebben gelegitimeerd. In het bijzonder dit arrest is de Hoge Raad dan ook zowel tijdens als na de oorlog kwalijk genomen. ${ }^{30}$

De discussie daarover begon al tijdens de bezettingsjaren. In een briefwisseling tussen de Leidse hoogleraar in het handelsrecht en burgerlijk procesrecht R.P. (Rudolph) Cleveringa (die van de protestrede) en raadsheer in de Hoge Raad P.A.J. (Pieter) Losecaat Vermeer werd dit debat gevoerd in termen van Radbruchs conflicterende waarden. Volgens Losecaat Vermeer had de Hoge Raad in de aanloop naar het Toetsingsarrest voor de keuze gestaan tussen de 'principieele' of 'consequente' - lees: op gerechtigheid georiënteerde - en de 'doelmatige' opvatting. De principiële lijn (wel toetsen) zou naar zijn oordeel echter tot een fatalistisch fiat justitia pereat mundus hebben geleid. De zittende leden van de Hoge Raad zouden in dat geval bijvoorbeeld tot aftreden of erger kunnen zijn gedwongen. De keuze voor doelmatigheid (niet toetsen) zou verstandiger zijn geweest, want 'vraagt veeleer van geval tot geval wat voor de recht-zoekenden de redelijkste (lees: de minst nadeelige) oplossing is en bekommert zich minder om het principieele of consequente. ${ }^{31}$ Tegen deze positie kwam Cleveringa fel in het geweer. Een keuze voor doelmatigheid kon in zijn ogen nooit inhouden dat men moest buigen voor het grootste bezettersonrecht: “'Op zijn post blijven” is een goede raad; maar dit kan nooit beteekenen "in zijn ambt blijven ten einde het omgekeerde te doen van wat men doen moet". 32 Voor Cleveringa was in dit geval slechts 'de "principieele" houding' als 'doelmatig' aan te merken. ${ }^{33}$ Met een voorbeeld dat door Radbruch zelf had kunnen zijn gebruikt, lichtte Cleveringa zijn standpunt toe: 'De rechtspraak van den H.R. [het Toetsingsarrest, WV] beteekent, dat als rechtsgeldig eigenaar wordt erkend iemand, die volgens het rechtsgevoel

30 Corjo Jansen m.m.v. Derk Venema, De Hoge Raad en de Tweede Wereldoorlog (Amsterdam: Boom, 2011), 121-34; Derk Venema, Leny de Groot-van Leeuwen en Thomas Mertens (red.), Onder de huidige omstandigheden. De Hoge Raad en het Toetsingsarrest 1942 (Den Haag: Boom Juridische uitgevers, 2008).

31 Brief Losecaat Vermeer aan Cleveringa, 11 november 1943, opgenomen in Venema e.a. (red.), Onder de huidige omstandigheden, 83. Voor meer recente beschouwingen die in deze richting tenderen, zie Job de Ruiter, 'De Hoge Raad in revisie', in Onrecht. Oorlog en rechtvaardigheid in de twintigste eeuw. Twaalfde jaarboek van het Nederlands Instituut voor Oorlogsdocumentatie, red. Madelon de Keizer, Mariska Heijmans-van Bruggen, Erik Somers, Meindert Fennema en Cees Maris (Zutphen: Walburg Pers, 2001), 124-51; Derk Venema, Rechters in oorlogstijd. De confrontatie van de Nederlandse rechterlijke macht met nationaal-socialisme en bezetting (Den Haag: Boom Juridische uitgevers, 2007), 153-91; 373-80.

32 Brief Cleveringa aan Losecaat Vermeer, 25 oktober 1943, opgenomen in Venema e.a. (red.), Onder de huidige omstandigheden, 79.

33 Brief Cleveringa aan Losecaat Vermeer, 12 november 1943, opgenomen in Venema e.a. (red.), Onder de huidige omstandigheden, 84. 
van ons volk heler is (ik denk aan iemand, die Joodsch eigendom verwerft); dit is één voorbeeld, dat waarschijnlijk met vele andere kan worden vermeerderd.'34

Het is niet moeilijk te bepalen aan welke zijde Radbruch in dit debat zou hebben gestaan. In een essay uit 1947 verwijst Radbruch naar Cicero ter ondersteuning van de stelling dat wat nuttig of doelmatig is ook steeds zedelijk juist moet zijn: 'Nie ist etwas nützlich, wenn es nicht gleichzeitig sittlich gut ist. Und nicht weil es nützlich ist, ist es sittlich gut, sondern weil sittlich gut, ist es auch nützlich.' ${ }^{35}$ In andere woorden: onder het voorwendsel van doelmatigheid mag men nooit posities rechtvaardigen of vergoelijken die in moreel of zedelijk opzicht onaanvaardbaar zijn. ${ }^{36}$

Binnen de kring van de VWR was het vooral de rooms-katholieke Carel van Nispen tot Sevenaer, volkenrechtsgeleerde, rechtsfilosoof en kasteelheer te Vierakker, die zich krachtig uitsprak tegen het Toetsingsarrest. In de bezettingstijd was hij op de achtergrond betrokken geweest bij de totstandkoming van een uitspraak van de rechtbank Arnhem waarin een bezettingsmaatregel wél expliciet aan het Landoorlogreglement werd getoetst. In deze uitspraak in kort geding, gewezen op 4 september 1944, maakte de president van de rechtbank Arnhem, Jhr. F.J.M. (Frans) van Nispen tot Sevenaer, korte metten met de argumentatie die de Hoge Raad in het Toetsingsarrest had gebezigd. Deze Van Nispen was een broer van Carel, die reeds in 1943 met hem correspondeerde over de principiële onjuistheid van het Toetsingsarrest. ${ }^{37}$

Carels gedachtevorming sloeg neer in de brochure 'Waarom de Hoge Raad faalde', die in 1945 werd gepubliceerd. Dit essay opent met een duidelijke positiebepaling in de doelmatigheid-versus-rechtvaardigheid-discussie. 'Het rechtsbewustzijn verstaat geen marchandeeren', schrijft Van Nispen. 'Een ongerechte beslissing is niet ten halve gerecht, kan niet voor een deel der gemeenschap ten nutte strekken. ${ }^{38}$ In een uitvoerig betoog hekelt Van Nispen de beslissing ook als technisch-juridisch onjuist, en als desastreus in zijn consequenties. Door zijn uitspraak had de Hoge Raad al het bezettersonrecht 'goedgepraat', door de 'formeele bekrachtiging'

34 Brief Cleveringa aan Losecaat Vermeer, 12 november 1943, opgenomen in Venema e.a. (red.), Onder de huidige omstandigheden, 85. Voor een vrijwel identiek voorbeeld bij Radbruch, zie Radbruch, 'Gesetzliches Unrecht', 339; voorts Robert Alexy, The Argument from Injustice. A Reply to Legal Positivism (Oxford: Oxford University Press, 2010), 5-10. Voor achtergrond bij de discussie tussen Losecaat Vermeer en Cleveringa, zie Kees Schuyt, R.P. Cleveringa. Recht, onrecht en de vlam der gerechtigheid (Amsterdam: Boom, 2019), 250-54.

35 Gustav Radbruch, 'Wissenschaft und Verbrechen', Volk und Zeit 5/2 (1947): 1.

36 Diezelfde opvatting had hij ook al verkondigd in 'Gesetzliches Unrecht', 345-346, hierboven aangehaald in paragraaf 2 (slot).

37 Rechtbank Arnhem, 4 september 1944, ECLI:NL:RBARN:1944:5, NJ 1945, 653. Zie voorts Jan Barendsen en Derk Venema, De rechtbank Arnhem en de Duitse bezetting (Nijmegen: Wolf Legal Publishers, 2004), 59-65.

38 Carel van Nispen tot Sevenaer, 'Waarom de Hoge Raad faalde' [1945], in Onder de huidige omstandigheden. De Hoge Raad en het Toetsingsarrest 1942, red. Derk Venema, Leny de Groot-van Leeuwen en Thomas Mertens (Den Haag: Boom Juridische uitgevers, 2008), 154. 
tot Nederlandse wet had hij ook aan de meest abjecte Duitse maatregelen 'een formeele wijding' gegeven. ${ }^{39}$

Van Nispens VWR-voordracht uit 1947, getiteld 'Had de Duitsche bezetter eenig gezag en hadden zijn maatregelen eenige rechtswaarde?', bevat een rechtsfilosofische bezinning op de vraag naar de rechtsgeldigheid van de bezettingsmaatregelen, waaraan hij in zijn eerdere brochure was voorbijgegaan. Vertrekkend vanuit het natuurrechtelijk beginsel dat uit onrecht geen recht kan ontstaan, beantwoordt hij in de loop van zijn betoog de beide vragen uit de titel ontkennend. Een onwettige overheid, zoals een vijandige bezettende macht die een onrechtvaardige oorlog is begonnen, kan slechts feitelijke macht uitoefenen, maar geen rechtsgeldig gezag. Dat verandert niet als een aantal van haar maatregelen het algemeen welzijn zou dienen of als haar maatregelen aan het volkenrecht, bijvoorbeeld de Haagse Conventie en het Landoorlogreglement, onderworpen zouden zijn. De toepasselijkheid van de Haagse Conventie betekent volgens Van Nispen slechts een juridische begrenzing van de feitelijke machtsuitoefening van een tirannieke bezetter, géén juridische erkenning van het door de bezetter de facto afgekondigde 'recht'. Alleen erkenning door of vanwege de gemeenschap kan ervoor zorgen dat 'tyranniek bestuur' uiteindelijk 'tot wettig bewind' wordt. ${ }^{40}$ Deze voordracht van Van Nispen werd binnen de VWR, ondanks kritische kanttekeningen, positief ontvangen ${ }^{41}$ en illustreert daarmee de tijdelijke 'herleving' van het natuurrecht die in de eerste jaren na de bevrijding in het bijzonder in Duitsland en in minder mate ook in Nederland was waar te nemen. ${ }^{42}$

Van Nispens rigoureuze en voluit natuurrechtelijke betoogtrant gaat echter aan de rechtsfilosofie van Radbruch voorbij. ${ }^{43}$ Radbruchs naoorlogse verwijzing naar natuurrecht - vooral in 'Fünf Minuten Rechtsphilosophie' - blijft immers beperkt tot specifieke situaties van extreem onrecht en concentreert zich op wat hij ziet als een 'vast bestand' van rechtsprincipes dat in de loop der eeuwen was gevormd

39 Van Nispen tot Sevenaer, 'Waarom de Hoge Raad faalde', 160-61.

40 Carel van Nispen tot Sevenaer, 'Had de Duitsche bezetter eenig gezag en hadden zijn maatregelen eenige rechtswaarde?', Handelingen van de Vereeniging voor Wijsbegeerte des Rechts XXXI 1 (1947): 19.

41 'Verslag van de Vergadering van 10 mei 1947', Handelingen van de Vereeniging voor Wijsbegeerte des Rechts XXXI 2 (1947).

42 Zie in dat verband Gerard Langemeijer, 'De huidige betekenis van het natuurrecht', Handelingen van de Vereeniging voor Wijsbegeerte des Rechts XXXXIII 1 (1958): 26-51; Hendrik Jan Hommes, Een nieuwe herleving van het natuurrecht (Zwolle: W.E.J. Tjeenk Willink, 1961).

43 Hetzelfde geldt wellicht voor andere, op de politiek en de rechtspraktijk gerichte interventies van Van Nispen in debatten rondom rechtsherstel en wederopbouw in de eerste naoorlogse jaren. Daarin betoont hij zich een voorstander van stevige, revanchistisch aandoende maatregelen, zoals Nederlandse annexatie van een groot deel van het Duitse grondgebied en de uitwinning van Duits privévermogen in Nederland ter vermindering van de collectieve oorlogsschadevordering op Duitsland (hetgeen in Nederland tussen 1945 en 1951 staande praktijk was), waarbij de rechtsgelijkheid en fundamentele rechten van individuele Duitsers onder druk konden komen te staan. Een bespreking van deze (complexe) problematiek valt echter buiten het bestek van dit betoog. Zie Carel van Nispen tot Sevenaer, Geen inpalming, wel inlijving van Duitsch gebied? (Zutphen: W.J. Thieme \& Cie, 1945); Carel van Nispen tot Sevenaer, 'Berooft de Nederlandse Staat individuele Duitsers?', Nederlands Juristenblad 30 (1950): 633-45. 
en inmiddels onder meer in mensen- en burgerrechtenverklaringen was neergelegd. Die principes kunnen volgens Radbruch wereldwijd op zulk breed draagvlak rekenen dat slechts 'moedwillige scepsis' de twijfel over hun geldigheid overeind kan houden. ${ }^{44}$

\section{De persoon in het recht}

De naoorlogse verschuiving in het denken van Radbruch heeft Alexy met deze verwijzing naar de harde kern van de mensenrechten in verband gebracht. Voor de oorlog stelde Radbruch immers dat de keuze voor Individualwerte, Kollektivwerte of Werkwerte een politieke was, waartegenover hij als rechtsfilosoof neutraliteit betrachtte. In de naoorlogse context brengt Radbruch daarop een correctie aan. Wanneer een wet tot doel heeft om, bijvoorbeeld, aan specifieke categorieën mensen fundamentele rechten te ontnemen, is de spanning tussen rechtszekerheid, rechtvaardigheid en doelmatigheid zo ondraaglijk geworden dat er niet langer sprake is van recht en dat recht dus zijn gelding verliest. ${ }^{45}$ Die schending van fundamentele rechten bevindt zich op het niveau van de Individualwerte, zoals Alexy terecht heeft opgemerkt. Ten aanzien van de doelmatigheid verliest Radbruch daarmee een deel van zijn neutraliteit. Een politieke keuze voor de juridische verwerkelijking van Individualwerte, Kollektivwerte of Werkwerte mag er immers niet toe leiden dat specifieke categorieën mensen van hun fundamentele rechten worden beroofd, omdat daarmee de bodem - dat wat nog minimaal aanvaardbaar is - onder de gerechtigheid wegvalt. Deze aanpassing heeft voor Radbruchs rechtsidee ten minste twee consequenties. Ten eerste gaan de Individualwerte ten opzichte van de Kollektivwerte en Werkwerte als een soort kritische maatstaf fungeren. Aldus wordt Radbruchs vooroorlogs relativisme ten aanzien van het recht als doelgerichte onderneming beteugeld, want aan een specifieke normatieve (onder)grens gebonden. Ten tweede verliest het bestanddeel rechtvaardigheid binnen de rechtsidee zijn zuiver formele karakter en wordt deels negatief-inhoudelijk bepaald door de mensenrechtelijk geïnspireerde drempelnorm in situaties van extreem onrecht. ${ }^{46}$

Interessant is dat Izaak Kisch in zijn VWR-voordracht 'De Persoon in het Recht' in 1947 op precies deze thematiek bij Radbruch ingaat en de drie ethische doeleinden waarop het recht gericht kan zijn aan een kritisch onderzoek onderwerpt. Zonder verwijzing naar Radbruchs naoorlogse essays - die hij wellicht nog niet kende - bekritiseert Kisch vooral Radbruchs concepties van de Kollektivwerte en de Werkwerte. Volgens Kisch hebben deze enerzijds op het collectief (de staat als 'Gesamtperson') en anderzijds op werken van kunst, wetenschap en cultuur gerichte waarden geen absolute of intrinsieke betekenis, zoals Radbruch veronderstelt, maar moeten ook deze waarden 'zich laten nooteren in termen van 
menschelijk welzijn, waarden voor de mensch. ${ }^{47}$ Om deze these te onderbouwen introduceert Kisch een onderscheid tussen 'welzijns-subjecten' en 'welzijns-elementen'. Terwijl menselijke personen welzijnssubjecten zijn, geldt dat niet voor de collectieve gemeenschappen of voor de werken van kunst, wetenschap en cultuur. Die entiteiten hebben hun waarde niet omwille van zichzelf, maar omdat mensen, de welzijnssubjecten, daaraan bepaalde welzijnselementen ontlenen. Kunstwerken bieden mensen bijvoorbeeld levensvreugde, terwijl het deelhebben aan een statelijke gemeenschap mensen onder meer vrijheid, veiligheid en het genot van publieke voorzieningen kan verschaffen. ${ }^{48}$

Kisch erkent dat zijn benadering dicht in de buurt komt van het utilitarisme van Jeremy Bentham, van wie hij de gedachte overneemt dat alle welzijnssubjecten aan elkaar gelijkwaardig zijn. Bentham heeft naar zijn mening echter onvoldoende ingezien dat veel welzijnselementen een collectieve oorsprong hebben - zij komen bijvoorbeeld voort uit 'taal en recht, moraal en religie' - en blijven dus afhankelijk van een leven in gemeenschap, van het collectief. ${ }^{49}$ In dat kader pleit Kisch voor een rangorde van welzijnselementen. ${ }^{50}$ Het benadrukken van de betekenis van collectieve en culturele goederen voor het welzijn van mensen mag er echter niet toe leiden dat hun waarde wordt verzelfstandigd en absoluut gesteld, een neiging die Kisch vooral bespeurt binnen de kantiaanse traditie in Duitsland. ${ }^{51}$ Dat het wenselijk is om collectieve entiteiten rechtspersoonlijkheid te geven, betekent nog niet dat zij eigenstandig de status van welzijnssubject (Zwecksubject in Radbruchs terminologie) zouden verdienen. De transpersonalistische opvatting, waarbij de gemeenschap wordt gezien als een 'grand individu' (de term is van Kisch), bergt onder meer het gevaar in zich dat het collectieve lichaam een eigen leven gaat leiden en als projectiescherm gaat fungeren voor driften en begeerten die in het samenleven van individuen binnen de gemeenschap worden afgeremd, zoals 'distinctie- en expansiedriften'. ${ }^{2}$ En dan ligt geweld op de loer:

'[H] et moet gezegd worden: waar de geest beheerscht wordt door transpersonalisme, daar wordt het gemoed beheerscht door agressiviteit van groep jegens groep, van staat jegens staat. En wanneer ik zie naar de duistere machten van onzen tijd, dan moet ik het uitspreken: le transpersonnalisme, voilà l'ennemi!'53

Izaak Kisch, 'De Persoon in het Recht', Handelingen van de Vereeniging voor Wijsbegeerte des Rechts XXX 1 (1947): 7.

48 Kisch, 'De Persoon in het Recht', 14.

49 Kisch, 'De Persoon in het Recht', 17

50 Kisch, 'De Persoon in het Recht', 10-12.

51 Kisch, 'De Persoon in het Recht', 23.

52 Kisch, 'De Persoon in het Recht', 25. Kisch wijst op deze plaats ter illustratie naar 'het hardnekkig succes van kreten om "Lebensraum"' en naar 'het kritiekloos aanvaarden van kolonisatorische projecten en annexionistische schema's'.

53 Kisch, 'De Persoon in het Recht', 27. 
Wat opvalt is dat Kisch in deze voordracht nagenoeg dezelfde beweging maakt als Radbruch zelf in zijn naoorlogse essays. Immers, ook bij Radbruch gaan de gelijke rechten van individuen, van menselijke 'welzijnssubjecten', expliciet als een kritische, uiterste maatstaf fungeren aan de hand waarvan de collectieve, bovenindividuele doeleinden van de statelijke rechtsorde kunnen worden getoetst. In vergelijkbare zin had overigens ook al Langemeijer zich in een artikel in het Nederlandsch Juristenblad in 1941 uitgelaten. ${ }^{54}$

Deze VWR-voordracht van Kisch kan worden gelezen als een verdiepend vervolg op zijn inaugurele rede 'Universalisme Oud en Nieuw' die hij in november 1945 uitsprak bij de aanvaarding van de leerstoel Wijsbegeerte des rechts en rechtsvergelijking aan de Universiteit van Amsterdam. ${ }^{55}$ Ook in deze rede staat de verhouding individu-gemeenschap centraal, in het licht van het aangerichte onrecht uit het recente verleden:

'En wat hebben wij nu ondervonden, gezien, gevoeld als onrecht? Dat een overheid haar onderdanen - en den vreemden die zij door expansie tot onderdanen had gemaakt - alle vrijheden, alle grondrechten heeft ontnomen. Dat een volk alleen zichzelf heeft doen gelden, anderen niet heeft geteld. En om het nu te zeggen in termen van gezag en gemeenschap: dat een gezag te ruim en een gemeenschap te eng is opgevat.' 56

In deze rede bekritiseert Kisch onder andere de sprong van 'een pluraliteit aan gemeenschappen' waarvan elk individu vanaf zijn geboorte deel uitmaakt, naar de absolute prioritering van de staat als einddoel, als een - bij Kisch benauwende 'universalistische' gemeenschap (het 'nieuwe universalisme' uit de titel). De rede eindigt met een pleidooi voor herwaardering van het 'oude universalisme' dat bestaat uit dienstbaarheid aan de mensheid, de mensengemeenschap als geheel. Juist bij dit 'oude universalisme' is ook het eigen vaderland het meest gebaat:

'Want gelooft het niet als men u zegt - en het wordt gezegd - dat dit oude universalisme in strijd zou kunnen komen met den zin tot de eigen gemeenschap. Wie met open oog door deze tijden is gegaan weet beter, weet dat de

54 Gerard Langemeijer, 'Gemeenschapsgedachte en Recht', Nederlandsch Juristenblad 10-11 (1941): 185-190, 201-210, in het bijzonder 202.

55 Volgens Langemeijer behoren deze twee voordrachten tot de kern van Kisch' in omvang beperkte rechtsfilosofische oeuvre. Zie Gerard Langemeijer, De Wijsbegeerte des Rechts en de Encyclopaedie der Rechtswetenschap sedert 1880 (Amsterdam: N.V. Noord-Hollandsche Uitgevers Maatschappij, 1963), 122-23.

56 Izaak Kisch, Universalisme Oud en Nieuw. Rede uitgesproken bij de aanvaarding van het ambt van hoogleraar aan de Universiteit van Amsterdam op 26 november 1945 (Leiden: A.W. Sijthoff, 1945), 4. 
slechte dienst aan het vaderland en het verraad aan de eigen gemeenschap de gezellen zijn niet van een te veel, maar van een te weinig aan humaniteit. ${ }^{57}$

Kisch, naast rechtsfilosoof ook advocaat, had zijn ogen in de oorlogsjaren opengehouden. Als Joodse Nederlander had hij de bezettingsjaren op een bijzonder moedige en wonderbaarlijke wijze doorstaan. ${ }^{58}$ Kenmerkend is zijn uiterst risicovolle uiting van protest bij zijn afscheidscollege als privaatdocent aan de juridische faculteit van de Universiteit van Amsterdam. Volgens Loe de Jong was Kisch daarmee waarschijnlijk de enige die als 'slachtoffer' een woord van protest heeft kunnen en durven laten klinken als reactie op de Duitse maatregel waarbij alle Joden uit overheidsdienst werden verwijderd. ${ }^{59}$

Ook als praktijkjurist had Kisch het juridisch onrecht van, onder meer, de maatregelen tegen de Joden van zeer nabij leren kennen. In reactie daarop was hij als advocaat in de bezettingstijd betrokken geweest bij processen waarin door echtscheiding ontbonden 'gemengde huwelijken' 60 weer werden hersteld, met als argument dat de eerder aangevoerde grond van overspel ('de grote leugen') op bedrog berustte. Deze juridische kunstgreep werd ingezet omdat een gemengd huwelijk de Joodse partner tegen de ergste vervolgingsmaatregelen van de bezetter kon beschermen. Langemeijer die destijds als rechter Kisch in een dergelijke

57 Kisch, 'Universalisme Oud en Nieuw', 24. Eenzelfde gedachte is ook - toegepast op het terrein van de kunst - terug te vinden bij Radbruch, Rechtsphilosophie, §7, 149-50: 'Ein Volk wird zum Nation nicht, indem es nach nationaler Eigenart strebt, sondern indem es sich allgemeingültigen Aufgaben selbstvergessen hingibt. Bewußte "Heimatskunst" und "Vaterlandsdichtung" bleibt künstlerisch immer zweiten Ranges. Aber Kunst, die sich um der Menschheit große Gegenstände müht, ist zugleich unentrinnbar national.'

58 Zie Winkel, 'I. Kisch', 174-76, voorts het beeldende relaas van Gerard Langemeijer, 'Levensbericht I. Kisch', in Jaarboek (Amsterdam: KNAW 1980), 205: 'Voorspoedig is Kisch' leven zelfs tijdens de voor Joden zo rampspoedige bezetting geweest. Zeker niet doordat hij zich zou hebben schuil gehouden. Integendeel, door tal van acties ten gunste van medejoden, waarbij hij even veel vindingrijkheid als brutaliteit aan de dag legde heeft hij zich voortdurend langs afgronden bewogen. De bescherming van de secretaris-generaal van binnenlandse zaken Frederiks zal hij te danken hebben gehad aan diens bewondering voor het feit dat Kisch de aan die bescherming verbonden voorwaarde: sequestratie in een kamp bij Barneveld uitdrukkelijk had afgewezen. Zijn moedige afscheidscollege als privaatdocent - de ontslagen hoogleraren en lectoren kregen daartoe niet de kans - is vermoedelijk toevallig onopgemerkt gebleven. Uiteindelijk is hij, met vrouw en kinderen naar het "Durchgangslager" Theresienstadt gebracht, maar door puur geluk is de vijand aan zijn deportatie naar een "Vernichtungslager" niet toegekomen.' Zie ook de terugblik op de oorlogsjaren van Kisch zelf in Van Dunné e.a. (red.), Acht civilisten, 114-16.

59 Loe de Jong, Het Koninkrijk der Nederlanden in de Tweede Wereldoorlog IV-2 (Den Haag: Martinus Nijhoff, 1972), 801; Winkel, 'I. Kisch', 174-75. Winkel vergelijkt Kisch' afscheidscollege met de protestrede van Cleveringa en stelt dat 'wellicht de risico's voor Kisch als direct slachtoffer van de ontslagen nog groter waren.' Voor een terugblik op dit college van Kisch zelf, zie Van Dunné e.a. (red.), Acht civilisten, 114. Kisch vertelt in het interview met Van Dunné dat hij waarschijnlijk als enige Joodse getroffene in staat is geweest om nog een afscheidscollege te geven, omdat ze hem als privaatdocent aanvankelijk waren 'vergeten' te ontslaan.

60 In de oorlogsjaren gebezigde term voor huwelijken waarbij een van de partners door de bezetter als Joods werd aangemerkt. 
rechtszaak meemaakte, doorzag de bedoeling achter deze 'loochening van de leugen' en speelde het spel mee. ${ }^{61}$

\section{Ethische rechtstheorie}

Kisch' voordracht over 'De Persoon in het Recht' in 1947 kon binnen de VWR op de nodige bijval rekenen. Langemeijer, vriend en latere collega van Kisch aan de Universiteit van Amsterdam, ${ }^{62}$ liet niet na zich in zijn reactie ook lovend uit te laten over Radbruch: '[D]es inleiders bewondering, vooral voor Radbruch, deel ik. Zijn boek is het mooiste, dat ik op rechtsphilosophisch gebied ken.' 63 Over Radbruchs onderscheid tussen Personswerte, Kollektivwerte en Werkwerte was Langemeijer een stuk minder te spreken. Andere denkers hadden naar zijn mening rijkere en interessantere waardesystemen ontwikkeld, zoals de neo-kantianen Hugo Münsterberg en Heinrich Rickert, en vooral de fenomenologische denkers Max Scheler en Nicolaï Hartmann. ${ }^{64}$ Vele jaren later, in 1961, tijdens zijn afscheidscollege als hoogleraar Wijsbegeerte des rechts aan de Rijksuniversiteit Leiden, blikte Langemeijer op Radbruchs bijdrage aan de rechtsfilosofie terug:

'Gewezen te hebben op dit belang van "waarden" voor de rechtsfilosofie en voor de politiek en daarmee op de nauwe samenhang die tussen rechtsfilosofie en politiek ook na de val van het achttiende-eeuwse natuurrecht nog bestaat, is nu reeds bijna een halve eeuw geleden, de verdienste van Radbruch geweest. Het is een verdienste, die men onvergankelijk zou willen noemen, indien een verdienste dat ooit is, ook wanneer men van mening is, wat ik ben, dat Radbruch in bijna elk detail van zijn behandeling van het probleem heeft gedwaald.' 65

Van alle leden die de VWR in haar honderdjarig bestaan heeft gehad, heeft ongetwijfeld Langemeijer in denken en doen het dichtst bij Radbruch gestaan. Net als

61 Izaak Kisch, 'De leugen geloochend. Een herinnering aan de bezettingstijd', in Speculum Langemeijer. 31 rechtsgeleerde opstellen, red. Jan Glastra van Loon, Arent van Haersolte en Jim Polak (Zwolle: W.E.J. Tjeenk Willink, 1982), 273-86; Winkel, 'I. Kisch', 175; voorts, voor nog een ander voorbeeld, Van Dunné e.a. (red.), Acht civilisten, 111-14.

62 Langemeijer was, naast al zijn drukke bezigheden als praktijkjurist, tussen 1945 en 1961 als buitengewoon hoogleraar in de inleiding in de rechtswetenschap en (later) wijsbegeerte des rechts verbonden aan de Rijksuniversiteit Leiden, en vervolgens, tussen 1960 en 1977 als docent in de rechtsfilosofie aan de Universiteit van Amsterdam. Zie C.W. Maris van Sandelingenambacht, 'G.E. Langemeijer', in: 16 juristen en hun filosofische inspiratie, red. Corjo Jansen, Jan Smits en Laurens Winkel (Nijmegen: Ars Aequi Libri, 2004), 156.

63 Handelingen van de Vereeniging voor Wijsbegeerte des Rechts XXX 2 (1947): 18.

64 Handelingen van de Vereeniging voor Wijsbegeerte des Rechts XXX 2 (1947): 18.

65 Gerard Langemeijer, 'Balans der Rechtsfilosofie', Algemeen Nederlands Tijdschrift voor Wijsbegeerte en Psychologie 54 (1961/62): 29. Voor een vergelijkbare beoordeling van Radbruch, zie Gerard Langemeijer, 'De waarde van het recht', in 't Exempel dwinght. Opstellen aangeboden aan prof. $m r$. I. Kisch, red. Hans Ulrich Jessurun d'Oliveira, Els Fischer-Keuls en Roland Drilsma (Zwolle: W.E.J. Tjeenk Willink, 1975), 286. 
Radbruch kon hij bogen op een indrukwekkende carrière als praktijkjurist. ${ }^{66}$ Maar ook als rechtsfilosoof komt Langemeijer Radbruch zeer nabij. Evenals Radbruch verknoopt Langemeijer de gelding van recht aan een ethische begrenzing, bijvoorbeeld in zijn VWR-voordracht 'Ethische Rechtstheorie' uit 1948:

'Zo zal het ook niet hinderen te blijven zeggen, dat een bepaald regelmatig tot stand gekomen wetsvoorschrift "geldt", mits men zich daardoor niet de blik laat benemen op deze fundamentele, zij het zelden practisch belangrijke waarheid: dat er geen absolute juridische gelding bestaat dan voorzover zij tevens een ethische is. ${ }^{67}$

Zelden praktisch belangrijk: in normale tijden zal als recht kunnen gelden wat conform de regels is uitgevaardigd. Toch is die ethische dimensie van de gelding van recht relevant. Bijvoorbeeld als zich een misdadig rechtsregime manifesteert. Weliswaar komt volgens Langemeijer zelfs aan een 'rechtsorde van weinig waardevolle inhoud' om haar 'orde-scheppende werking' hoge waarde en dus gelding toe, die inhoud kan in potentie tot 'een zo negatieve waarde' dalen, 'dat haar vervanging door een betere zelfs ten koste van aanmerkelijke wanorde de waarde der orde overtreft'. In die uitzonderlijke omstandigheden komt de gelding van die rechtsorde en daarmee de gehoorzaamheidsplicht in het geding en kan zelfs revolutie volgens Langemeijer gerechtvaardigd zijn. ${ }^{68}$

Dit standpunt doet sterk denken aan Radbruchs extreem onrecht-criterium. Ook bij Radbruch is recht normaal gesproken datgene wat op de gebruikelijke wijze is uitgevaardigd en sociaal effectief is, maar kan, zoals gezegd, een wet haar gelding verliezen als de drempel van extreem onrecht wordt overschreden. ${ }^{69}$ Radbruchs beroemde essay 'Gesetzliches Unrecht und übergesetzliches Recht', waarin hij dit criterium ontvouwt, verscheen voor het eerst in de Süddeutsche Juristenzeitung in augustus 1946. Langemeijer laat dat essay - dat hij destijds wellicht nog niet kende -ongenoemd in zijn VWR-voordracht van 1948, maar borduurt daarin voort op zijn eigen oratie 'Ons oordeel over wat recht moet zijn', die hij op 7 juni 1946 uitsprak bij de aanvaarding van zijn leeropdracht als buitengewoon hoogleraar aan de Rijksuniversiteit Leiden. Reeds in deze oratie stelt Langemeijer dat

66 Radbruch was ten tijde van de Weimarrepubliek onder meer minister van Justitie geweest. Langemeijer werd na de bevrijding advocaat-fiscaal bij de Bijzondere Raad van Cassatie, het hoogste rechtsprekend orgaan op het terrein van de bijzondere rechtspleging. Daarnaast was hij tussen 1947 en 1957 advocaat-generaal bij de Hoge Raad en aansluitend tot 1973 procureur-generaal. Zie Maris, 'G.E. Langemeijer', 155; Joggli Meihuizen, Noodzakelijk kwaad. De bestraffing van economische collaboratie in Nederland na de Tweede Wereldoorlog (Amsterdam: Boom, 2003).

67 Gerard Langemeijer, 'Ethische Rechtstheorie', Handelingen van de Vereeniging voor Wijsbegeerte des Rechts XXXIII 1 (1948): 5 (cursivering van Langemeijer). Vergelijk dit citaat van Langemeijer met de volgende stelling van Radbruch, Rechtsphilosophie, §5, 134: 'Nur die Moral vermag die verpflichtende Kraft des Rechts zu begründen.'

68 Langemeijer, 'Ethische Rechtstheorie', 18-19. Zie in gelijke zin ook Maris, 'G.E. Langemeijer', 161. Maris verduidelijkt dat bij Langemeijer de 'gelding' van recht gelijk staat aan de 'morele gehoorzaamheidsplicht'.

69 Zie supra, paragraaf 2 (slot); Radbruch, 'Gesetzliches Unrecht', 345-46. 
ook een 'minder juiste' wetsbepaling omwille van de rechtszekerheid eerbiediging verdient, maar dat die legitimatie wel 'haar grenzen' kent: '[H]et is, minstens theoretisch, mogelijk, dat een wet zoo slecht is, dat de spreuk zou gelden: "Beter rechtsonzekerheid dan onrechtszekerheid!"'70 Daarmee zou die wet haar gelding verliezen. Langemeijer is derhalve, nog net iets eerder dan Radbruch, met een eigen - zij het weinig vastomlijnd - extreem onrecht-criterium gekomen.

Alexy heeft Radbruch wel als een inclusieve niet-positivist getypeerd, als een rechtsfilosoof wiens afstand tot het rechtspositivisme met een brede waaier aan mogelijke politieke en morele opvattingen verenigbaar blijft. ${ }^{71}$ Die aanduiding is net zo goed van toepassing op Langemeijer. Ook hij bewaarde de nodige afstand tot zowel rechtspositivisme als tot rechtsfilosofie die zo in elkaar zit dat zij, zoals Langemeijer het ergens omschreef, wel 'een nauwe samenhang moet hebben met de godsdienstige overtuiging van haar ontwerpers'. ${ }^{72}$ Met deze formulering doelde Langemeijer op de wijsbegeerte der wetsidee van Herman Dooyeweerd ${ }^{73}$ en zijn school - een filosofie die hij om haar grote oorspronkelijkheid wel zeer bewonderde. ${ }^{74}$ In 1958 hield Langemeijer nog een VWR-voordracht over 'De huidige beteekenis van het natuurrecht'. In het debat dat daarop volgde, plaatste hij zich impliciet in een traditie van 'niet-natuurrechtelijk gezinde non-positivisten', waartoe volgens hem ook Otto von Gierke, Rudolf Stammler, Radbruch, Leonard Nelson en in het Nederlands taalgebied Roelof Kranenburg zouden behoren. ${ }^{75}$

Langemeijers ethische rechtstheorie laveert, met andere woorden, tussen twee sterke rechtsfilosofische tradities waarbij ze zich niet langer thuis voelt: die van het rechtspositivisme (zoals dat van Kelsen) en die van het natuurrecht (zoals het Thomisme), op een manier die doet denken aan Radbruch. Enerzijds beklemtoont Langemeijer het belang van eerbied voor het positieve recht, ook als de inhoud niet fraai is. Anderzijds is hij er vast van overtuigd dat 'zowel de verplichting om het positief recht na te leven als het oordeel over wat recht behoort te zijn niet anders zijn dan toepassingen van het oordeel over goed en kwaad. ${ }^{\text {76 }}$ Uiteindelijk is, zoals gezegd, de vraag naar rechtsgelding een ethische. Het hoofdprobleem in de rechtsfilosofie van Langemeijer vormt vervolgens de vraag hoe morele overtuigingen en waarden nog een zekere mate van objectiviteit, evidentie en intersub-

70 Gerard Langemeijer, Ons oordeel over wat recht moet zijn. Rede uitgesproken bij de aanvaarding van het ambt van buitengewoon hoogleeraar aan de Rijksuniversiteit Leiden op 7 juni 1946 (Zwolle: W.E.J. Tjeenk Willink, 1946), 4. Zie over deze passage ook Maris, 'G.E. Langemeijer', 163.

71 Alexy, 'Gustav Radbruchs Rechtsbegriff', 249.

72 Langemeijer, De Wijsbegeerte des Rechts, 93. Cursivering WV.

73 Herman Dooyeweerd (1894-1977) was binnen de VWR een betrekkelijk actief en gerespecteerd lid. In 1947 verloor hij met negen tegen vier stemmen de strijd om het voorzitterschap (ter opvolging van Kranenburg) van Vrij. Zie Handelingen van de Vereeniging voor Wijsbegeerte des Rechts XXXI 2 (1947): 6-7.

74 Langemeijer, De Wijsbegeerte des Rechts, 92. Zie voorts Bas Hengstmengel, 'Paul Scholten en Herman Dooyeweerd: het gesprek dat nooit plaatsvond', NJLP 39/1 (2010): 12, 29.

75 Handelingen van de Vereeniging voor Wijsbegeerte des Rechts XXXXIII 2 (1958): 48-49.

76 Langemeijer, De Wijsbegeerte des Rechts, 128. 
jectieve aanvaardbaarheid kunnen verkrijgen en behouden, als de klassieke natuurrechtsleer met zijn vaste waarde-hiërarchie niet langer voldoet. ${ }^{77}$

\section{Vrijs herdenkingsrede (slot)}

Tijdens de VWR-vergadering van 17 december 1949 sprak de voorzitter M.P. Vrij een herdenkingsrede uit ter gelegenheid van het dertigjarig bestaan. Hij memoreerde de oprichting van de Vereniging, pal na de Eerste Wereldoorlog in 1918/1919 en ging eerst in op de bestaande verwarring, als gevolg van rechtsfilosofische 'verstrooidheid' in de jaren twintig, over het exacte jaar van oprichting. ${ }^{78}$ Belangrijker dan die kwestie was voor hem echter de vraag of het toevallig was dat de VWR juist vlak na een wereldoorlog was ontstaan. En hoe zat dat in 1949, opnieuw in de directe nasleep van een vernietigende oorlog? Vrij refereerde aan de fraaie rede die zijn voorganger als VWR-voorzitter, de veelzijdige Roelof Kranenburg, in 1946 had gehouden tijdens de eerste naoorlogse vergadering, 'De beteekenis der rechtsphilosophie voor dezen tijd'. Kranenburg had in die voordracht naar de bloeitijd van de Griekse filosofie verwezen, in de directe nasleep van de vreselijke Peloponnesische Oorlog, en had vervolgens, teruggekeerd naar de eigen tijd, gereflecteerd op de tegenstelling tussen het als recht 'gevoelde' en het als recht 'gestelde', die in bezettingstijd zo nijpend was geweest. ${ }^{79}$ Nog steeds in datzelfde kader vroeg Vrij zich in 1949 af: filosoferen wij ondanks een oorlog ('de geest gaat boven het geweld!') of filosoferen wij dankzij de oorlog ('het geweld dringt den geest tot bezinning') ${ }^{80}$ Uit het bovenstaande mag blijken dat het filosoferen vanuit de onrechtervaring van oorlog, dus 'dankzij' de oorlog, het Nederlandse rechtsfilosofische debat in die eerste naoorlogse jaren gemarkeerd heeft, hetgeen bij de drie door mij behandelde actieve VWR-leden heel duidelijk naar voren komt.

Vrij ging in zijn herdenkingsrede ook in op het open karakter van de VWR, omdat 'ieder als lid kan toetreden'. Hij sprak waarderende woorden over 'hoe alle richtingen en scholen zich hier steeds hebben thuisgevoeld; men herinnere zich uit den

77 Voor Langemeijers uitwerking van een antwoord op deze vraag die in dit bestek achterwege moet blijven, zie Langemeijer, 'Balans der Rechtsfilosofie', 21-31; Maris, 'G.E. Langemeijer', 158-59.

78 Zowel de oprichtingsvergadering (21 juni) als de eerste gewone VWR-vergadering (15 november) vond in 1919 plaats. Bij het - pas jaren later - aanvragen van de rechtspersoonlijkheid van de VWR is men echter uitgegaan van de datum van een eerste verkennende bijeenkomst met 'een dozijn belangstellenden' op 28 december 1918. Het geharrewar daarover is nooit opgelost. Zie Vrij, 'Herdenkingsrede', 3-5.

79 Roelof Kranenburg, 'De beteekenis der rechtsphilosophie voor dezen tijd', Handelingen van de Vereeniging voor Wijsbegeerte des Rechts XXVIII 1 (1946): 3-6. Ter inleiding van het debat had Kranenburg het in 1946 zelfs nog scherper gesteld: 'Wel nimmer toch is de zelf-verzekerdheid van het zuivere positivisme zóó aan het wankelen gebracht als thans; wel nimmer is het zich terugtrekken op eigen positief-rechtelijk terrein voor de beoefenaars der rechtswetenschap zóó onbevredigend geweest als in het huidige tijdsgewricht.' Zie Handelingen van de Vereeniging voor Wijsbegeerte des Rechts XXVIII 2 (1946): 4. 
aanvang Clara Wichmann en P. Tideman!'81 Voordat Vrij, aan het slot van zijn rede, zou overgaan tot het benoemen van professor Kranenburg tot erelid van de Vereniging, raakte hij nog een laatste thema aan dat ook na honderd jaar VWR nog actueel is: de 'wisselwerking tussen rechtsbespiegeling en rechtservaring'. Filosoferen in gemeenschappelijkheid is een groot goed, betoogde hij, maar onder een klemmende voorwaarde:

'[...] filosoferen over recht moet gevoed worden uit het feitelijk hanteren van recht. Dat doet elk practisch jurist en dat kan ook doen die rechtsgenoot die op àl zijn handelingen zich bezint, de filosoof. De rechtsfilosofie worde steeds wezenlijke filosofie, maar zij onderhoude dan de band met de juridische vakwetenschappen; niet alleen omderwille van deze, die aan wijsgerige bezinning behoefte hebben, maar ook om haarszelfs wil, om zelf niet te verschralen en te verdorren $[\ldots]$ ]. 82

Concluderend kan worden opgemerkt dat de VWR in de eerste jaren na de oorlog niet zozeer wereldvreemd was, maar - ondanks het beschouwende en elitaire karakter - juist sterk georiënteerd bleef op de rechtspraktijk. Men filosofeerde op een betrekkelijk abstracte wijze, maar wel vanuit een grote, veelal concrete en intense betrokkenheid bij fundamentele, normatieve vraagstukken die in de rechtszaal, politiek en samenleving speelden. De sterke focus op de complexe relatie tussen recht en gerechtigheid maakt de VWR-voordrachten uit deze bewogen jaren nog altijd lezenswaardig en urgent. ${ }^{83}$

81 Vrij, 'Herdenkingsrede', 6. Aan de genoemde VWR-leden Clara Wichmann (1885-1922) en Pieter Tideman (1871-1943) moet ik in dit bestek helaas voorbijgaan.

82 Vrij, 'Herdenkingsrede', 6-7.

83 Zie, in Radbruchs geest, in aanvulling hierop ook Cotterrell, 'The Role of the Jurist', 520: 'The jurist's task is surely not to try to rationalise conflict away, but to identify where it lies and how law can respond to it: the question here is how to preserve law as a universal good in the face of moral and political disagreement or simply in the face of popular disinterest in questions about ultimate values. In short, the juristic issue is how the idea of law can survive in the socio-historic conditions it faces. So the jurist's concerns are sociological as much as philosophical, but neither philosophy nor sociology can remove these concerns: they remain the responsibility of the jurist.' 
Appendix: Inleidingen gehouden bij de VWR tussen 1946 en 1959 en gepubliceerd in de Handelingen van de Vereeniging voor Wijsbegeerte des Rechts

\begin{tabular}{|c|c|c|}
\hline Auteur(s) & Titel & Uitgave \\
\hline Kranenburg & $\begin{array}{l}\text { De beteekenis der rechtsphilosophie voor dezen } \\
\text { tijd }\end{array}$ & 1946 XXVIII \\
\hline Loenen & $\begin{array}{l}\text { Wezen en functie van Dikè: Een analyse van het } \\
\text { gerechtigheidsbegrip bij de Grieken }\end{array}$ & 1946 XXIX \\
\hline Kisch & De Persoon in het Recht & $1947 \mathrm{XXX}$ \\
\hline $\begin{array}{l}\text { Van Nispen tot } \\
\text { Sevenaer }\end{array}$ & $\begin{array}{l}\text { Had de Duitsche bezetter eenig gezag en } \\
\text { hadden zijn maatregelen eenige rechtswaarde? }\end{array}$ & 1947 XXXI \\
\hline Winkel & Vrijheid en gelijkheid door broederschap & 1948 XXXII \\
\hline Langemeijer & Ethische rechtstheorie & 1948 XXXIII \\
\hline $\begin{array}{l}\text { Hooykaas \& } \\
\text { Van Oyen }\end{array}$ & Ethiek en recht & 1949 XXXIV \\
\hline Boasson & $\begin{array}{l}\text { De meester over de macht in de staat en de wil } \\
\text { van het volk }\end{array}$ & 1950 XXXV \\
\hline Mekkes & $\begin{array}{l}\text { Het gezag van het recht tegenover de macht } \\
\text { van het onrecht }\end{array}$ & 1951 XXXVI \\
\hline $\begin{array}{l}\text { Kazemier \& } \\
\text { Van der Ven }\end{array}$ & Gerechtigheid en belangenwaardering & 1952 XXXVII \\
\hline Van Praag & $\begin{array}{l}\text { De betekenis van Kelsens werk voor de } \\
\text { wijsbegeerte van het recht }\end{array}$ & 1953 XXXVIII \\
\hline $\begin{array}{l}\text { Van Nispen tot } \\
\text { Sevenaer \& } \\
\text { Tammes }\end{array}$ & $\begin{array}{l}\text { De gerechtigheid in de internationale } \\
\text { verhoudingen en de weerstand die zij daar } \\
\text { ondervindt }\end{array}$ & 1954 XXXIX \\
\hline $\begin{array}{l}\text { Langemeijer \& } \\
\text { Kisch }\end{array}$ & $\begin{array}{l}\text { Kan de afwijking van dwingend recht van de } \\
\text { staat tot positief recht worden? }\end{array}$ & 1955 XXXX \\
\hline $\begin{array}{l}\text { Duynstee \& } \\
\text { Verburg }\end{array}$ & Misbruik van recht door de burgerlijke eigenaar & 1956 XXXXI \\
\hline $\begin{array}{l}\text { Hoetink \& } \\
\text { Dengerink }\end{array}$ & $\begin{array}{l}\text { Komt aan de historische ontwikkeling een } \\
\text { normatieve betekenis toe voor het proces der } \\
\text { rechtsvorming? }\end{array}$ & 1957 XXXXII \\
\hline $\begin{array}{l}\text { Loeff \& } \\
\text { Langemeijer }\end{array}$ & De huidige betekenis van het natuurrecht & 1958 XXXXIII \\
\hline $\begin{array}{l}\text { De Langen \& } \\
\text { Van Haersolte }\end{array}$ & $\begin{array}{l}\text { De bruikbaarheid van de zogenoemde } \\
\text { empirisch-analytische methode voor de } \\
\text { rechtswetenschap }\end{array}$ & 1959 XXXXIV \\
\hline
\end{tabular}

